\title{
Laboratory Test Code
}

National Cancer Institute

\section{Source}

National Cancer Institute. Laboratory Test Code. NCI Thesaurus. Code C83322.

A character or string that represents the short code name of the laboratory test. 